\title{
ARBUSCULAR MYCORRHIZAL FUNGAL COMMUNITIES IN PASTURE AND TROPICAL RIPARIAN FOREST ECOSYSTEMS IN GUAJARÁ- MIRIM, RONDÔNIA, BRAZIL
}

\author{
Jéssica Archanjelo de Jesus ${ }^{1}$, Ana Lucy Caproni ${ }^{2}$, Cristiane Figueira da Silva ${ }^{3}$, Marcos Gervasio Pereira ${ }^{4}$, \\ Otávio Augusto Queiroz dos Santos ${ }^{5}$, Ricardo Luiz Louro Berbara ${ }^{4}$ \\ ${ }^{1}$ Universidade Federal de Rondônia, Graduação em Gestão Ambiental, E-mail: jessica-archanjelo@ @otmail.com; \\ ${ }^{2}$ Universidade Federal de Rondônia, Departamento Acadêmico de Ciências Sociais e Ambientais, E-mail: alcaproni @ unir.br; \\ ${ }^{3}$ Universidade Federal Rural do Rio de Janeiro, Programa de Pós-Graduação em Ciências Ambientais e Florestais, Seropédica, Rio de \\ Janeiro, Brazil, E-mail: cfigueirasilva@yahoo.com.br; \\ ${ }^{4}$ Universidade Federal Rural do Rio de Janeiro, Departamento de Solos, Seropédica, Rio de Janeiro, Brazil, E-mail: \\ mgervasiopereira01@gmail.com*; \\ ${ }^{5}$ Programa de Pós-Graduação em Agronomia - Ciência do Solo, Departamento de Solos, Seropédica, Rio de Janeiro, Brazil, E-mail \\ otavioqueiroz7@hotmail.com
}

Received for publication: 18/02/2020 - Accepted for publication: 17/12/2020

\begin{abstract}
Resumo
Comunidades de fungos micorrízicos arbusculares em ecossistemas de pastagem e floresta tropical ripária no município de Guajará-Mirim/RO. Compreender a dinâmica dos organismos do solo nos ecossistemas naturais pode ser uma ferramenta muito útil para determinar a qualidade dos ecossistemas florestais e agrícolas no estado de Rondônia. A hipótese deste trabalho é que a comunidade de fungos micorrízicos arbusculares (FMA) varia em função do sistema de uso do solo e da sazonalidade. O trabalho objetivou avaliar a composição e diversidade da comunidade de FMA em ecossistemas de pastagens e floresta tropical ripária em regeneração natural, no município de Guajará-Mirim/RO. Coletou-se, aleatoriamente, 10 amostras simples de solo, em cada um dos ecossistemas, em três épocas do ano (seca/2018; chuvosa/2018; e seca/2019). Foram avaliadas a riqueza de espécies de FMA e densidade dos esporos; a frequência de ocorrência de espécies; os índices de diversidade de Shannon-Wiener (H') e dominância de Simpson; e o número de amostra ideal. A riqueza de espécies de FMA variou entre as áreas e as estações, com tendência à maior riqueza no pasto, na estação seca/2018. As espécies dominantes de FMA foram Glomus macrocarpum e Acaulospora mellea nos dois ecossistemas; A pastagem, na estação seca/2018, apresentou maior diversidade de espécies (H') de FMA comparado a floresta tropical ripária na estação chuvosa/2018 e na estação seca/2019; a pastagem na estação seca/2019 diferiu em 100\% da floresta tropical ripária, na composição da comunidade de espécies de FMA; são necessárias mais de 10 amostras simples para identificar um número maior de espécies de FMA em áreas de pastagem e floresta tropical ripária, no município de Guajará-Mirim/RO.

Palavras-chave: diversidade de espécies; ecossistema ripário; qualidade do solo.
\end{abstract}

Abstract
Understanding the dynamics of soil organisms in natural environments can be very useful for determining the
quality of forest and agricultural ecosystems. The hypothesis of this work is that the FMA community varies
depending on the land use system and seasonality. This study aimed to assess arbuscular mycorrhizal fungal
(AMF) communities in pasture and regenerating riparian forest (Forest) sites in Guajará-Mirim, Rondônia,
Brazil. Ten soil samples were randomly collected from each ecosystem in three seasons (2018 dry and rainy
seasons and 2019 dry season). AMF species richness (SR), frequency, spore density, Shannon-Wiener (H')
diversity index, Simpson's dominance index, and ideal sample size were determined. Species richness varied
among sites and seasons, with a tendency toward higher richness in pasture soil in the 2018 dry season. The
dominant AMF species in both ecosystems were Glomus macrocarpum and Acaulospora mellea. The pasture
site in the 2018 dry season had higher AMF diversity (H') than the riparian forest in the 2018 rainy season and
the 2019 dry season. The complete linkage distance between the pasture site in the 2019 dry season and all other
sites/seasons was $100 \%$. More than 10 soil samples are needed to accurately determine the richness of AMF
species in pasture and riparian forest sites in Guajará-Mirim, Brazil.
Keywords: species diversity; riparian ecosystem; soil quality.

\section{INTRODUCTION}

Information on the dynamics of soil organisms in natural environments can be very useful for determining the quality of forest and agricultural ecosystems. Equilibrium between plant and soil microbial communities, including arbuscular mycorrhizal fungi (AMF), is necessary for maintaining soil fertility, organic matter decomposition, nutrient cycling and other biogeochemical processes. AMF contribute greatly to plant growth and development (CHEN et al., 2018). These microorganisms help crops absorb nutrients, especially in low-P soils (CHEN et al., 2018; KUMAR et al., 2019), which are very common in Brazil. Further benefits include enhanced nutrient cycling and soil aggregate stability; AMF are important biotic factors for sustainable soil management 
(CHEN et al., 2018). These symbiotic fungi also contribute to forest succession, as they promote the establishment of mid- and late-successional species, paving the way for the return of climax communities of plants, animals and fungi (SOUSA et al., 2014). These benefits help maintain plant biodiversity and ecosystem functions.

It is essential to understand the effects of riparian forest and agricultural species on AMF populations and vice versa (BRAGHIROLLI et al., 2012). Various studies (SILVA et al., 2016; WINAGRASKI et al., 2019) have investigated the characteristics of AMF communities in different ecosystems, but controversial results were obtained. Cristo et al. (2018) found that the conversion of an Atlantic forest fragment to pasture reduced AMF species richness, suggesting that deforestation affected the diversity of AMF communities. Silva et al. (2016), on the other hand, observed that AMF species richness was not significantly altered by pasture establishment.

The dynamics of AMF communities may indicate which factors induce or inhibit processes associated with soil organic matter cycling and plant nutrition. For this analysis, it is necessary to first identify the plant and AMF species that occur in a given ecosystem. The hypothesis of this work is that the FMA community varies depending on the land use system and seasonality. This study aimed to investigate the relationship between land use, seasonality and AMF communities. AMF species richness, diversity, and spore density were determined in a riparian forest undergoing natural regeneration and a pasture site along the Madeira-Mamoré River, GuajaráMirim, Rondônia, Brazil.

\section{MATERIAL AND METHODS}

The study was conducted in two sites located about $1000 \mathrm{~m}$ apart on the banks of the Madeira-Mamore river in Guajará-Mirim, Rondônia, Brazil. The local climate is classified by the Köppen-Geiger system as tropical wet and dry (Aw), with most rainfall occurring between October and April and the lowest amounts (10 to $20 \mathrm{~mm}$ ) between June and August. The average annual temperature is $26.6^{\circ} \mathrm{C}$ and the average annual precipitation 1488 $\mathrm{mm}$. The soil is dominated by sandy and clayey sediments. One site is a pasture on a private property on the city outskirts. The area was covered by tropical riparian vegetation until the 1990s, when deforestation began for cattle production. The other site is a tropical riparian forest fragment allowed to undergo natural regeneration since 1998. Table 1 summarizes the most abundant vegetation in each locality.

Table 1. Floristic composition of pasture and regenerating forest sites located on the banks of the MadeiraMamoré river in Guajará-Mirim, Rondônia, Brazil.

Tabela 1. Composição florística das áreas de pastagem e floresta tropical ripária em regeneração natural ao longo do rio Madeira-Mamoré, no entorno da cidade de Guajará-Mirim/RO.

\begin{tabular}{ll}
\hline Site & Floristic information \\
\hline Pasture & This area was occupied by "Juquira" 10 years ago. An area of 13 ha was plowed \\
& and planted with a mixture of grasses. Currently, it supports different types of \\
& livestock (horses, goats, cattle, and chickens). Vegetation is dominated by the \\
& genera Genipa, Cariniana, Ficus, Chrysalidocarpus, Syagrus, Panicum, \\
& Brachiaria, Machaerium, Ziziphus, Handroanthus, Melissa, Struthanthus, \\
& Jacaranda, Pyrenoglyphis, Saccharum, and Swartzia.
\end{tabular}

Regenerating tropical riparian forest
The area was isolated more than 20 years ago in an effort to promote natural regeneration. At the time, there was little understory vegetation. Currently, the most abundant genera are Cordia, Syagrus, Clusia, Rollinia, Philodendron, Capsicum, Inga, Pinus, Schizolobium, Vanilla, Haworthia, Handroanthus, Astrocaryum, Cedrela, Monstera, and Theobroma.

\section{Sampling procedure}

Soil samples $(500 \mathrm{~mL}$ ) were collected close to plant roots at depths of 0 to $20 \mathrm{~cm}$ in September 2018 (end of the dry season), December 2018 (rainy season), and May 2019 (beginning of the dry season). Ten samples were collected from randomly chosen points in each site. Then, samples were allowed to dry in the shade and divided into two parts, one of which was sent to the soil laboratory of the Federal Rural University of Rio de Janeiro for chemical and physical analysis (Table 2) (DONAGEMMA et al., 2011) and the other was packed in plastic bags and stored at $10{ }^{\circ} \mathrm{C}$ until microbial analysis.

Table 2. Chemical and physical attributes of soils under pasture and regenerating tropical riparian forest on the banks of the Madeira-Mamoré river in Guajará-Mirim, Rondônia, Brazil in the year 2018. 
Tabela 2. Análises químicas e físicas das amostras de solos das áreas de pasto e de floresta tropical ripária em regeneração natural, nas margens do rio Madeira-Mamoré, município de Guajará-Mirim/RO, ano de 2018 .

\begin{tabular}{|c|c|c|c|c|c|c|c|}
\hline \multirow{2}{*}{ Site } & pH & $\mathbf{P}$ & $\mathbf{C a}$ & Mg & $\mathbf{N a}$ & $\mathbf{K}$ & $\mathbf{H}+\mathbf{A l}$ \\
\hline & & $\mathrm{mg} \mathrm{kg}^{-1}$ & \multicolumn{5}{|c|}{ 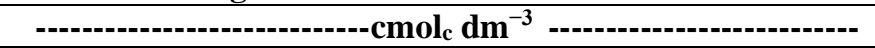 } \\
\hline Pasture & 6.54 & 47.50 & 8.50 & 3.00 & 0.004 & 0.03 & 1.70 \\
\hline Forest & 5.68 & 3.30 & 1.70 & 4.50 & 0.003 & 0.008 & 3.40 \\
\hline \multirow{2}{*}{ Site } & SB & ECEC & BS & TOC & Clay & Sand & Silt \\
\hline & & & $\%$ & $\mathrm{~g} \mathrm{~kg}^{-1}$ & & $\%$ & \\
\hline Pasture & 11.53 & 13.23 & 87.00 & 19.7 & 4.1 & 60.40 & 35.50 \\
\hline Forest & 6.21 & 9.61 & 65.00 & 22.31 & 3.0 & 65.60 & 31.40 \\
\hline
\end{tabular}

Analyses were conducted in 2018. SB, sum of bases; ECEC, effective cation exchange capacity; BS, base saturation; TOC, total organic carbon.

\section{Characterization of AMF communities}

Fungal spores were extracted from soil samples $(100 \mathrm{~mL})$ by the wet-sieving method (GERDEMANN; NICOLSON, 1963) followed by centrifugation in 50\% (v/v) sucrose solution. An aliquot of the spore extract was transferred to a Petri dish for identification. Spores were grouped by size, color and shape. Selected spores from each group were mounted on microscope slides in polyvinyl alcohol/lactic acid/glycerol (PVLG) and crushed gently with a coverslip to expose the inner walls. Spores from the same group were mounted in a 1:1 (v/v) mixture of PVLG and Melzer reagent under another coverslip. Color results and morphological characteristics were used for fungal identification. AMF species were identified by comparison with descriptions from the International Culture Collection of (Vesicular) Arbuscular Mycorrhizal Fungi (http://invam.caf.wvu.edu) and Schenck and Perez (1988). Total spore counts and spore counts by species were determined by light microscopy with oil immersion.

Total spore density was calculated as the number of AMF spores per $100 \mathrm{~mL}$ of soil, and AMF species density $\left(D_{i}\right)$ as the number of AMF spores of a given species per $100 \mathrm{~mL}$ of soil. The frequency of occurrence of each species $\left(F_{i}\right)$ was calculated for each sampling period (dry and wet seasons) by the equation $F_{i}=J_{i} / K \times 100$, where $J_{i}$ is the number of samples in which species $i$ occurs and $K$ is the total number of samples. Total species richness $(S)$ was calculated as the total number of species identified in $100 \mathrm{~mL}$ of soil. Species dominance was classified into four categories based on frequency values (ZHANG et al., 2004): $F_{i}>50 \%$, dominant; $30 \%<F_{\mathrm{i}} \leq$ $50 \%$, very common; $10 \%<F_{\mathrm{i}} \leq 30 \%$, common; and $F_{i} \leq 10 \%$, rare. The Shannon-Wiener diversity index $\left(H^{\prime}\right)$ was calculated by the equation $H^{\prime}=-\sum\left[\left(X_{i} / X_{\mathrm{o}}\right) \times \log \left(X_{i} / X_{\mathrm{o}}\right)\right]$, where $X_{i}$ is the spore density of species $i$ and $X_{\mathrm{o}}$ is the total spore density. Simpson's dominance index $(C)$ was calculated as $C=S\left(X_{i} / X_{\mathrm{o}}\right)^{2}$.

Species accumulation curves were constructed by plotting the cumulative number of species identified in each site on the $y$-axis and the cumulative number of samples on the $x$-axis (SCHILLING; BATISTA, 2008). These plots provide valuable information on the minimum sampling effort required to adequately represent fungal communities.

Spore density, diversity, and dominance data were subjected to the nonparametric Kruskal-Wallis test $(P$ $<0.05$ ) using Assistat version 7.7 (SILVA; AZEVEDO, 2016). Spore density data were subjected to complete linkage clustering with Pearson's distance $(1-r)$ as a metric to identify similarities and differences between sites and seasons. Cluster analysis was performed using Statistic version 8.0.

\section{RESULTS}

\section{AMF community composition}

In total, $40 \mathrm{AMF}$ taxa were identified in pasture and forest sites, including 7 families (Acaulosporaceae, Ambisporaceae, Archaeosporaceae, Dentiscutataceae, Gigasporaceae, Glomeraceae, and Paraglomeraceae) and 12 genera (Table 3). Of the total taxa recorded, 33 (83\%) were identified at the species level, $7(17 \%)$ at the genus level, and 1 could not be identified. Considering all sites and seasons, it was found that the majority of AMF species belonged to the genus Acaulospora (11, 27.5\%), followed by Glomus (7, 17.5\%), Ambispora (5, 12.5\%), Scutellospora (4, 10\%), Rhizophagus (3, 7.5\%), Funneliformis (2, 5\%), and Gigaspora (2, 5\%). Appendicispora, Fuscutata, Racocetra, and Paraglomus were represented by a single species each.

Table 3. Mean spore density (SD), frequency of occurrence (FO), and dominance level (D) of arbuscular mycorrhizal fungal species found in pasture $(\mathrm{P})$ and regenerating tropical riparian forest $(\mathrm{F})$ soils in September 2018 (late dry season), December 2018 (rainy season), and May 2019 (early dry season) in Guajará-Mirim, Rondônia, Brazil. 
Tabela 3. Densidade média de esporos, frequência de ocorrência (FO\%) e grau de dominância das espécies de FMAs em amostras de solos coletadas em setembro/2018 (final da época seca), dezembro/2018 (época chuvosa) e maio/2019 (início da época seca) nos ecossistemas de pastagem (P) e floresta tropical ripária (F), no município de Guajará-Mirim/RO.

\begin{tabular}{|c|c|c|c|c|c|c|c|c|c|}
\hline \multirow{3}{*}{ Family/species } & \multicolumn{2}{|c|}{ SD } & \multirow{2}{*}{ FO(D) } & \multicolumn{2}{|c|}{ SD } & \multirow{2}{*}{ FO(D) } & \multicolumn{2}{|c|}{ SD } & \multirow{2}{*}{ FO(D) } \\
\hline & $\mathbf{P}$ & $\mathbf{F}$ & & $\mathbf{P}$ & $\mathbf{F}$ & & $\mathbf{P}$ & $\mathbf{F}$ & \\
\hline & \multicolumn{3}{|c|}{ September 2018} & \multicolumn{3}{|c|}{ December 2018} & \multicolumn{3}{|c|}{ May 2019} \\
\hline Acaulosporaceae & & & & & & & & & \\
\hline $\begin{array}{l}\text { Acaulospora bireticulata F.M. } \\
\text { Rothwell \& Trappe }\end{array}$ & 8 & - & $5(\mathrm{R})$ & - & - & - & - & - & - \\
\hline $\begin{array}{l}\text { Acaulospora denticulata Trappe \& } \\
\text { Gerd. (1974) }\end{array}$ & 8 & - & $5(\mathrm{R})$ & - & - & - & - & - & - \\
\hline $\begin{array}{l}\text { Acaulospora excavata Ingleby \& C. } \\
\text { Walker (1994) }\end{array}$ & - & - & - & - & 3 & $5(\mathrm{R})$ & - & - & - \\
\hline $\begin{array}{c}\text { Acaulospora foveata Trappe \& } \\
\text { Janos (1982) }\end{array}$ & 7 & - & $10(\mathrm{R})$ & - & 3 & $5(\mathrm{R})$ & - & - & - \\
\hline Acaulospora koskei Błaszk. (1995) & - & - & - & - & - & - & - & 29 & $10(\mathrm{R})$ \\
\hline $\begin{array}{l}\text { Acaulospora mellea Spain \& N.C. } \\
\text { Schenck (1984) }\end{array}$ & 61 & 102 & 65(D) & 124 & 123 & 45(D) & 10 & 125 & $10(\mathrm{R})$ \\
\hline $\begin{array}{l}\text { Acaulospora morrowiae Spain \& } \\
\text { N.C. Schenck (1984) [as } \\
\text { 'morrowae'] }\end{array}$ & 21 & - & $15(\mathrm{C})$ & 6 & 3 & $10(\mathrm{R})$ & 10 & - & $10(\mathrm{R})$ \\
\hline $\begin{array}{l}\text { Acaulospora rehmii Sieverd. \& S. } \\
\text { Toro (1987) }\end{array}$ & - & 57 & $5(\mathrm{R})$ & - & - & - & - & - & - \\
\hline $\begin{array}{l}\text { Acaulospora scrobiculata Trappe } \\
\text { (1977) }\end{array}$ & 19 & 25 & $25(\mathrm{C})$ & 86 & - & $15(\mathrm{C})$ & 87 & 64 & $25(\mathrm{C})$ \\
\hline Acaulospora $\mathrm{sp} 1$ & - & 51 & $15(\mathrm{C})$ & 12 & 5 & $10(\mathrm{R})$ & - & - & - \\
\hline $\begin{array}{l}\text { Acaulospora tuberculata Janos \& } \\
\text { Trappe (1982) }\end{array}$ & 35 & - & $20(\mathrm{C})$ & 13 & - & $15(\mathrm{C})$ & 85 & - & $15(\mathrm{C})$ \\
\hline $\begin{array}{l}\text { Kuklospora colombiana (Spain \& } \\
\text { N.C. Schenck) Kaonongbua, J.B. } \\
\text { Morton \& Bever (2010) } \\
\text { Ambisporaceae }\end{array}$ & 14 & 61 & $30(\mathrm{C})$ & 48 & 21 & $25(\mathrm{C})$ & 85 & 28 & $30(\mathrm{C})$ \\
\hline $\begin{array}{l}\text { Ambispora brasiliensis (B.T. Goto, } \\
\text { L.C. Maia \& Oehl) C. Walker, M. } \\
\text { Krüger \& A. Schüßler (2011) }\end{array}$ & 10 & - & $10(\mathrm{R})$ & - & - & - & - & - & - \\
\hline $\begin{array}{l}\text { Ambispora callosa (Sieverd.) C. } \\
\text { Walker, Vestberg \& Schüßler }\end{array}$ & 25 & - & $10(\mathrm{R})$ & 38 & - & $15(\mathrm{C})$ & - & - & - \\
\hline $\begin{array}{l}\text { Ambispora granatensis J. } \\
\text { Palenzuela, N. Ferrol \& Oehl (2011) }\end{array}$ & 103 & 25 & $15(\mathrm{C})$ & 18 & 7 & $10(\mathrm{R})$ & - & - & - \\
\hline $\begin{array}{l}\text { Ambispora leptoticha C. Walker, } \\
\text { Vestberg \& Schüßler (2007) }\end{array}$ & - & - & - & 37 & - & $15(\mathrm{C})$ & 167 & - & $15(\mathrm{C})$ \\
\hline $\begin{array}{l}\text { Ambispora reticulata Oehl \& } \\
\text { Sieverd (2012) } \\
\text { Archaeosporaceae }\end{array}$ & - & 29 & $5(\mathrm{R})$ & - & 3 & $5(\mathrm{R})$ & - & - & - \\
\hline $\begin{array}{l}\text { Appendicispora jimgerdemanni } \\
\text { Spain, Oehl \& Sieverd. } 2006 \\
\text { Dentiscutataceae }\end{array}$ & 8 & - & $5(\mathrm{R})$ & - & - & - & - & - & - \\
\hline $\begin{array}{l}\text { Fuscutata heterogama Oehl, F.A. } \\
\text { Souza, L.C. Maia \& Sieverd. (2008) } \\
\text { Gigasporaceae }\end{array}$ & 14 & 23 & $20(\mathrm{C})$ & 117 & - & $30(\mathrm{C})$ & 383 & 5 & $45(\mathrm{VC})$ \\
\hline $\begin{array}{l}\text { Gigaspora decipiens I.R. Hall \& } \\
\text { L.K. Abbott (1984) }\end{array}$ & - & 72 & $20(\mathrm{C})$ & - & - & - & 17 & 8 & $15(\mathrm{C})$ \\
\hline $\begin{array}{l}\text { Gigaspora rosea T.H. Nicolson \& } \\
\text { N.C. Schenck (1979) }\end{array}$ & - & 20 & $5(\mathrm{R})$ & - & - & - & - & - & - \\
\hline $\begin{array}{l}\text { Racocetra verrucosa Oehl, F.A. } \\
\text { Souza \& Sieverd. }(2008)\end{array}$ & - & 85 & $15(\mathrm{C})$ & 7 & - & $10(\mathrm{R})$ & 28 & 58 & $15(\mathrm{C})$ \\
\hline $\begin{array}{l}\text { Scutellospora calospora C. Walker } \\
\text { \& F.E. Sanders (1986) }\end{array}$ & 8 & 5 & $15(\mathrm{C})$ & 30 & 19 & $25(\mathrm{C})$ & 42 & - & $5(\mathrm{R})$ \\
\hline $\begin{array}{l}\text { Scutellospora cerradensis Spain \& J. } \\
\text { Miranda (1996) }\end{array}$ & 5 & - & $5(\mathrm{R})$ & 85 & - & $10(\mathrm{R})$ & 9 & - & $10(\mathrm{R})$ \\
\hline Scutellospora $\mathrm{sp} 1$ & - & - & - & - & - & - & 21 & - & $5(\mathrm{R})$ \\
\hline
\end{tabular}




\begin{tabular}{|c|c|c|c|c|c|c|c|c|c|}
\hline $\begin{array}{l}\text { Scutellospora weresubiae Oehl, F.A. } \\
\text { Souza \& Sieverd. (2008) } \\
\text { Glomeraceae }\end{array}$ & 9 & - & $10(\mathrm{R})$ & 9 & - & $5(\mathrm{R})$ & - & - & - \\
\hline $\begin{array}{l}\text { Funneliformis caledonium (T.H. } \\
\text { Nicolson \& Gerd.) C. Walker \& A. } \\
\text { Schüßler (2010) }\end{array}$ & 2 & - & $5(\mathrm{R})$ & - & - & - & - & - & - \\
\hline $\begin{array}{l}\text { Funneliformis geosporum T.H. } \\
\text { Nicolson \& Gerd.) C. Walker \& A. } \\
\text { Schüßler }\end{array}$ & 83 & - & $25(\mathrm{C})$ & 11 & 3 & $15(\mathrm{C})$ & 10 & 12 & $15(\mathrm{C})$ \\
\hline $\begin{array}{l}\text { Glomus formosanum C.G. Wu \& } \\
\text { Z.C. Chen (1986) }\end{array}$ & 5 & - & $5(\mathrm{R})$ & 2 & - & $5(\mathrm{R})$ & - & - & - \\
\hline $\begin{array}{l}\text { Glomus heterosporum G.S. Sm. \& } \\
\text { N.C. Schenck (1985) }\end{array}$ & 19 & - & $10(\mathrm{R})$ & - & - & - & - & - & - \\
\hline $\begin{array}{l}\text { Glomus macrocarpum Tul. \& C. Tul. } \\
\text { (1845) }\end{array}$ & 159 & 437 & $85(\mathrm{D})$ & 614 & 717 & 95(D) & 1081 & 391 & $70(\mathrm{D})$ \\
\hline Glomus sp1 & - & - & - & - & - & - & 104 & 40 & $35(\mathrm{VC})$ \\
\hline Glomus sp2 & 29 & 32 & $35(\mathrm{VC})$ & 18 & 16 & $20(\mathrm{VC})$ & 17 & 62 & $20(\mathrm{C})$ \\
\hline Glomus sp3 & 38 & - & $5(\mathrm{R})$ & - & - & - & - & - & - \\
\hline Glomus sp4 & - & - & - & - & 3 & $5(\mathrm{R})$ & - & - & - \\
\hline $\begin{array}{l}\text { Rhizoglomus } \quad \text { microaggregatum } \\
\text { Sieverd., G.A. Silva \& Oehl (2014) }\end{array}$ & 118 & 14 & $30(\mathrm{C})$ & 264 & 13 & $35(\mathrm{VC})$ & 475 & 328 & $40(\mathrm{VC})$ \\
\hline $\begin{array}{l}\text { Rhizophagus clarus C. Walker \& A. } \\
\text { Schüßler (2010) }\end{array}$ & 44 & - & $25(\mathrm{C})$ & 205 & - & $25(\mathrm{C})$ & 91 & - & $15(\mathrm{C})$ \\
\hline $\begin{array}{l}\text { Rhizophagus diaphanus C. Walker } \\
\text { \& A. Schüßler (2010) }\end{array}$ & 11 & 7 & $15(\mathrm{C})$ & - & 9 & $5(\mathrm{R})$ & 70 & 19 & 25C) \\
\hline $\begin{array}{l}\text { Paraglomeraceae } \\
\text { Paraglomus brasilianum J.B. } \\
\text { Morton \& D. Redecker (2001) }\end{array}$ & 47 & - & $30(\mathrm{C})$ & 4 & - & $5(\mathrm{R})$ & - & - & - \\
\hline Unidentified species & 35 & 104 & $35(\mathrm{VC})$ & 39 & 44 & $50(\mathrm{D})$ & 395 & 97 & 40(VC) \\
\hline Species richness & 28 & 17 & 34 & 22 & 16 & 27 & 20 & 14 & 21 \\
\hline
\end{tabular}

$\mathrm{R}$, rare; $\mathrm{C}$, common; $\mathrm{VC}$, very common; $\mathrm{D}$, dominant.

Species richness varied among seasons and sites (Table 3). Thirty-four species occurred in the 2018 dry season, 27 in the 2018 rainy season, and 21 in the 2019 dry season. The number of AMF species recorded in the 2018 dry season was greater than that recorded in the 2018 rainy season, mainly in pasture soil. In total, 34 species were found in pasture soil, 28 in the 2018 dry season, 22 in the 2018 rainy season, and 20 in the 2019 dry season. Only 23 species were collected from forest soil, 17 in the 2018 dry season, 16 in the 2018 rainy season, and 14 in the 2019 dry season. Species richness also varied between early and late dry seasons, with 24 species recorded in September 2018 and 21 in May 2019.

The most frequently occurring species in all sites and seasons was Glomus macrocarpum, followed by Acaulospora mellea (Table 3). These AMF fungi were dominant in at least two of the three seasons analyzed, whereas most other species were rare or common.

\section{Species diversity}

Species diversity was significantly higher in the pasture site in the 2018 dry season than in other sites/seasons (Figure 1). Simpson's dominance index was higher in the riparian forest site in the 2018 rainy season, when the Shannon-Wiener diversity index was low, indicating low species evenness.

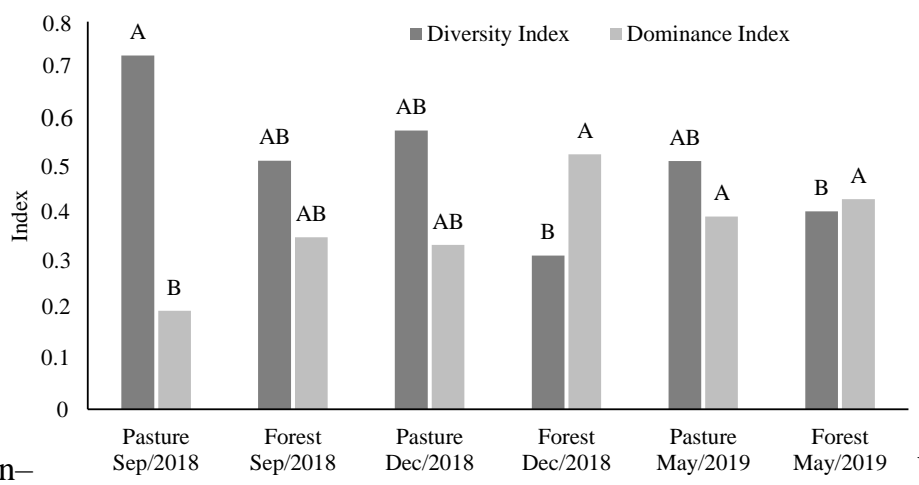

Figure 1. Shannon- Sep/2018 Sep/2018 Dec/2018 Dec/2018 May/2019 May/2019 Wiener diversity index and Simpson's dominance index of arbuscular mycorrhizal fungal species occurring in pasture and regenerating tropical riparian forest soils in September 2018 (late dry season), December 2018 (rainy 
season), and May 2019 (early dry season) in Guajará-Mirim, Rondônia, Brazil. Different letters above bars indicate significant differences (Kruskal-Wallis test, $P<0.05$ ).

Figura 1. Índices de diversidade de Shannon-Wiener e de dominância de Simpson de FMAs, em amostras de solos coletadas em setembro/2018 (final da época seca), dezembro/2018 (época chuvosa) e maio/2019 (início da época seca) nos ecossistemas de pastagem (pasto) e floresta tropical ripária (floresta), no município de Guajará-Mirim/RO. (Barras seguidas de mesma letra não diferem entre si nos ecossistemas nas três épocas de amostragens pelo teste de Kruskal-Wallis a 5\% de probabilidade).

Complete linkage clustering of sites and seasons showed that the AMF community in the pasture site in the 2019 dry season was separated from other sites/seasons by a linkage distance of 1 (Figure 2). The other clusters were separated by distances lower than 0.5 .

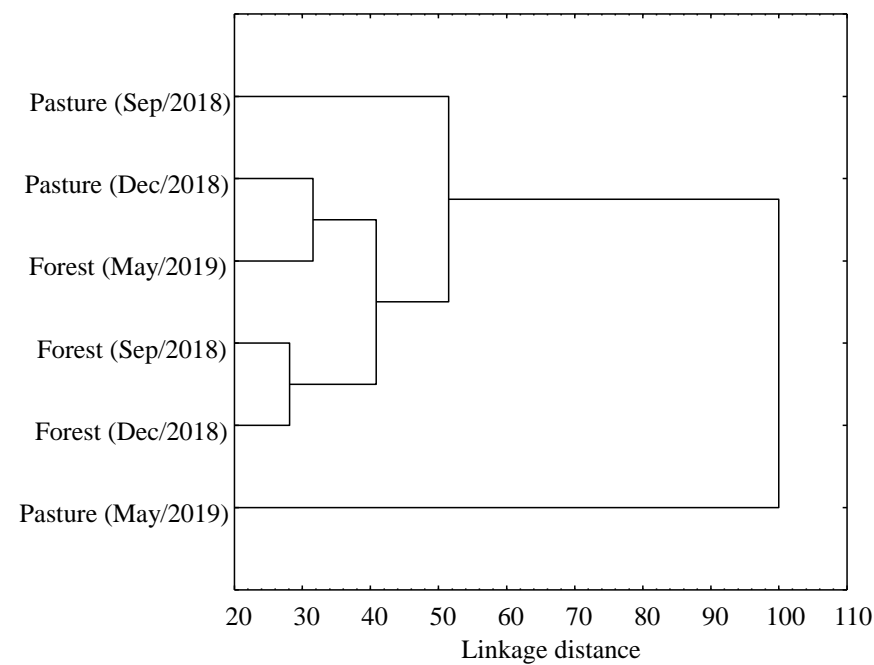

Figure 2. Complete linkage clustering of arbuscular mycorrhizal fungal communities in pasture and regenerating tropical riparian forest soils in September 2018 (late dry season), December 2018 (rainy season), and May 2019 (early dry season) in Guajará-Mirim, Rondônia, Brazil.

Figura 2. Análise de agrupamento das comunidades de FMAs de amostras de solo coletadas em setembro/2018 (final da época seca), dezembro/2018 (época chuvosa) e maio/2019 (início da época seca) nas áreas de pastagem (pasto) e floresta tropical ripária (floresta), no município de Guajará-Mirim/RO.

\section{AMF spore density}

The mean spore density of AMF did not differ significantly among sites and seasons $(P>0.05)$ (Figure 3 ). However, we observed a trend toward an increase in sporulation from the 2018 rainy season to the 2019 dry season. In these seasons, spore density tended to be higher in pasture than in forest soil.

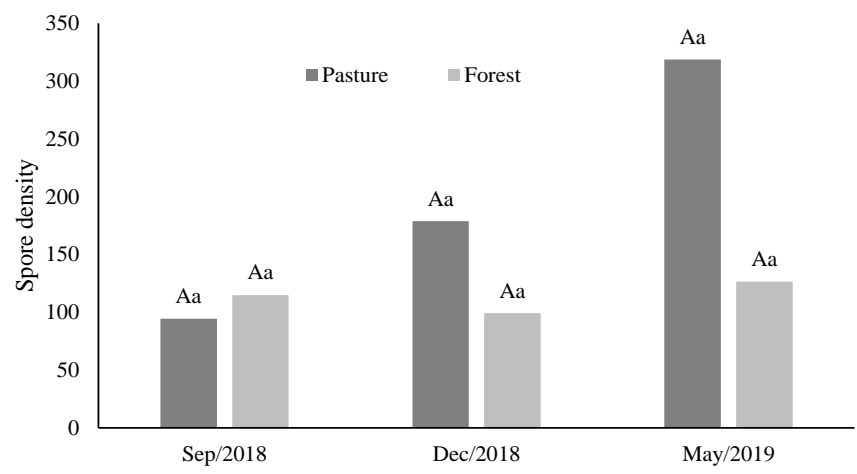

Figure 3. Mean density of arbuscular mycorrhizal fungal spores in pasture and regenerating tropical riparian forest soils in September 2018 (late dry season), December 2018 (rainy season), and May 2019 (early dry season) in Guajará-Mirim, Rondônia, Brazil. Different lowercase letters above bars indicate significant 
differences between sites, and different uppercase letters indicate significant differences between seasons (Kruskal-Wallis test, $P<0.05$ ).

Figura 3. Densidade média dos esporos de FMAs em amostras de solos coletadas em setembro/2018 (final da época seca), dezembro/2018 (época chuvosa) e maio/2019 (início da época seca) nas áreas de pastagem (pasto) e floresta tropical ripária (floresta), no município de Guajará-Mirim/RO. (Barras seguidas de mesma letra não diferem entre si nas áreas e três épocas de amostragens pelo teste de Kruskal-Wallis a $5 \%$ de probabilidade. Letras minúsculas comparam as áreas dentro de cada época, e letras maiúsculas comparam as épocas dentro de cada área)

\section{Species accumulation curve}

The species accumulation curve for the pasture site in the 2019 dry season reached a plateau with nine samples; on the other hand, 10 samples were not sufficient to reach a plateau in the 2018 dry and rainy seasons (Figure 1A). The species accumulation curves for the forest site did not reach a plateau, indicating that more than 10 samples are needed to accurately determine AMF species richness in tropical riparian forest soils, both in rainy and dry seasons (Figure 4B).
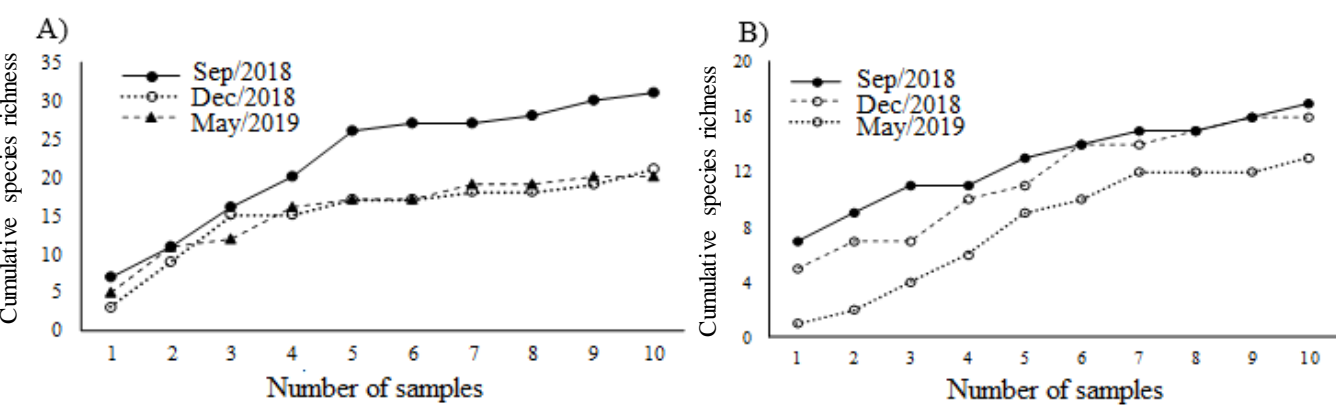

Figure 4. Species accumulation curve showing the number of arbuscular mycorrhizal fungal species plotted against the number of samples collected from pasture (A) and regenerating tropical riparian forest (B) soils in September 2018 (late dry season), December 2018 (rainy season), and May 2019 (early dry season) in Guajará-Mirim, Rondônia, Brazil.

Figura 4. Curva espécie-número de amostras de solos e número cumulativo de espécies de FMAs no ecossistema de pastagem (A) e floresta tropical ripária em regeneração natural (B) ao longo do Rio MadeiraMamoré, localizado no município de Guajará-Mirim/RO, em três épocas (setembro/2018-final da época seca; dezembro/2018 - época chuvosa; e maio/2019 - início da época seca).

\section{DISCUSSION}

The number (forty) of AMF taxa found in this study was next to observed by Stürmer and Siqueira (2011) in a pasture and secondary forest (42 taxa) and lower than that observed by Caproni et al. (2003) in reforestation sites recovering from bauxite mining ( 57 taxa), both in the Amazon region.

AMF communities were dominated by Glomus and Acaulospora, evidence of the high adaptability and tolerance of these genera. Similar results were observed in several Brazilian (CRISTO et al., 2018) and international (BI et al., 2020) ecosystems. According to Pereira et al. (2014), the high number of species in Glomus and Acaulospora, added to their dissemination and adaptation capabilities, explains the dominance of these genera in most ecosystems. Miranda et al. (2005) identified Acaulospora and Glomus in different crop rotation and pasture systems in the Cerrado. Camara et al. (2016) reported that these two genera had the highest species richness in restinga fragments in Rio de Janeiro, Brazil.

G. macrocarpum and A. mellea were observed in all seasons and sites with high frequency and spore density. The former is commonly found with high frequency in Brazilian ecosystems. For instance, Santos et al. (2019) identified G. macrocarpum in native forest, Cerrado, and pasture soils. Camara et al. (2016) and Nogueira et al. (2016) identified the species in all samples collected from forest fragments (frequency of 100\%). Similarly, A. mellea can be found in Cerrado (ASSIS et al., 2014), Atlantic Forest (SILVA et al., 2016), and Amazon (CAPRONI et al. 2003) biomes. G. macrocarpum and A. mellea were found in equal proportions with high frequency in pasture and agricultural sites and secondary forests at different stages of succession in the MédioParaíba region, Rio de Janeiro, in a study by Silva et al. (2016). The authors found other species (with lower frequencies) that were also observed in the present study, such as Acaulospora foveata, Acaulospora scrobiculata, 
Kuklospora colombiana, and Archaeospora leptoticha, which indicates that these species occur in various Brazilian ecosystems.

Some AMF species occurred exclusively in the riparian forest site: Acaulospora excavata, A. koskei, A. rehmii, A. reticulata, and Gigaspora rosea. Of these, only A. rehmii was identified by Winagraski et al. (2019) as occurring in the Amazon region. The following species occurred only in the pasture site: A. bireticulata, A. denticulata, A. tuberculata, A. brasiliensis, A. callosa, A. leptoticha and A. jimgerdemanni, F. caledonium, G. formosanum, G. heterosporum, Glomus sp3, P. brasilianum, R. clarus, S. cerradensis, Scutellospora sp1, and S. weresubiae (Table 3). The higher number of exclusive species in the pasture site $(n=16)$ may be associated with the high soil $\mathrm{pH}$ (6.54) compared with that of riparian forest soil ( $\mathrm{pH} 5.68$ ). Higher soil $\mathrm{pH}$ and the presence of nonnative species in the pasture site are factors that contribute to nutrient availability, plant diversity, and soil moisture variations. Pasture soil had higher $\mathrm{P}, \mathrm{Ca}, \mathrm{Na}, \mathrm{K}$, sum of bases, base saturation, clay, and silt contents than forest soil (Table 2). However, $\mathrm{Mg}, \mathrm{H}+\mathrm{Al}$, total organic carbon, and sand contents were higher in riparian soil (Table 2). Boerave et al. (2019) observed that AMF species richness increased with increasing soil $\mathrm{pH}$, as found in the present study.

Some species occurred in both sites in all seasons, such as A. foveata, A. mellea, A. morrowiae, A. scrobiculata, A. sp1, Ambispora granatensis, Funneliformis geosporum, Fuscutata heterogama, Gigaspora decipiens, Glomus macrocarpum, Glomus sp1, Glomus sp2, Kuklospora colombiana, Racocetra verrucosa, Rhizoglomus microaggregatum, Rhizophagus diaphanus, and Scutellospora calospora (Table 3). Winagraski et al. (2019) argued that AMF species are selected by the environmental conditions under which the host develops. Some species are rare in forest ecosystems. Those that are ubiquitous could be used as inoculants for forest species.

Acaulospora sp1, Glomus sp1, Glomus sp2, Glomus sp3, Glomus sp4, and Scutellospora sp1 were identified only at the genus level, and probably, constitute species not yet described; more studies in the evaluated areas they can even provide the registration of species not yet known to science.

AMF species richness and Shannon-Wiener diversity varied among sites and seasons. There was a trend toward higher richness and diversity in the pasture site, especially in the 2018 dry season. The high Simpson's dominance and low Shannon-Wiener diversity indices observed in the forest site indicate low species evenness as a result of the dominance of G. macrocarpum and A. mellea. Boerave et al. (2019) stated that abiotic factors, such as climate, seasonality, geographical region, and land use and management may have greater influence over AMF communities than vegetation. In contrast, Pereira et al. (2014) argued that plant cover is one of the most important factors determining the occurrence of AMF species. In the current study, plant cover, soil moisture, and $\mathrm{pH}$ seemed to be determinant factors of AMF species richness and diversity.

The linkage distance of 1 between pasture in the 2019 dry season and other sites/seasons may be related to high sporulation of Glomus macrocarpum, A. scrobiculata, A. tuberculata, A. leptoticha, F. heterogama, Glomus sp1, K. colombiana, R. microaggregatum, R. diaphanus, Scutellospora sp1, and the unidentified species. In the study of Santos et al. (2019), pasture and native forest ecosystems had similar characteristics and were grouped together, attributed to the similar Shannon-Wiener indices. In contrast, in the current study, the ShannonWiener index did not support the differences observed in AMF populations between ecosystems.

The lack of significant differences in spore density between sites and seasons may be due to the high data variability. In the pasture site, spore density was $90 \%$ higher in the 2018 rainy season and $240 \%$ higher in the 2019 dry season in relation to the 2018 dry season. Furthermore, spore density was $80 \%$ higher in the 2019 dry season than in the 2018 rainy season. In the 2018 rainy season and 2019 dry season, the parameter was 80 and $150 \%$ higher in the pasture site than in the riparian forest, respectively. The higher values in the pasture site in the rainy season and early dry season (2019) can be attributed to the high seed germination of invasive plants. Seeds remain dormant in the dry season and then germinate, forming new roots and increasing symbiotic associations with AMF. The pasture site was dominated by Brachiaria decumbens Sptapf. throughout the year and had low livestock density, which can also contribute to plant diversity. These results are in line with other studies showing that plant cover may influence AMF sporulation (PEREIRA et al., 2014; BI et al., 2020). Silva et al. (2016) found more AMF spores in a pasture site than in an Atlantic Forest site.

AMF spore density was probably more affected by soil fertility and vegetation than by soil texture (Table 2). Soils with sandy texture, as those evaluated in this study, are characterized by excessive drainage. Pasture soils generally have higher drainage, evaporation, evapotranspiration, and density of fine roots than forest soils, thus promoting spore production, despite the high soil fertility.

In the riparian forest site, there was less variation in spore production between sampling times. This site has been regenerating for more than 20 years and has high occurrence of Scheelea sp. This palm species is commonly found in wet soils or dry land and may be influencing spore production. According to Carrenho et al. (2000), the sporulation pattern of AMF is related to root volume, which is lower in pioneer than in climax species. As natural regeneration progresses, the higher volume of roots in contact with AMF propagules stimulates sporulation. However, climax species seem to depend less on AMF in their initial stages of growth, as discussed

FLORESTA, Curitiba, PR, v. 51, n. 3, p. 658-667, jul/set 2021

Jesus, J. A. et.al.

ISSN eletrônico 1982-4688

DOI: $10.5380 /$ rf.v51 i3. 71802 
by Carrenho et al. (2000); therefore, AMF development in root systems is limited and the percentage of colonization is low, reducing spore production.

In general, species accumulation curves did not reach a plateau, except for the 2019 dry season. This analysis was also applied to natural and managed systems in the Amazon (STÜRMER; SIQUEIRA, 2011) and Atlantic Forest (PEREIRA et al., 2014), and curve stabilization was not observed. It is known that total AMF richness is often underestimated when populations are evaluated by taking into consideration the presence of spores, as many species may colonize root fragments or occur in the soil only in the form of hyphae. Therefore, for greater accuracy, future studies should collect more than 10 soil samples and/or use trap cultures (PEREIRA et al., 2014) to stimulate sporulation of AMF species generally not found in field samples.

In AMF community studies, it is important to determine the ideal sample size for each season so as to collect the highest number of AMF species, as populations may vary with climate change. Santos et al. (2019), in assessing AMF species diversity in native forest, pasture, and Cerrado ecosystems in Guajará-Mirim, Brazil, concluded that the ideal sample size in the dry season is greater than 15 . In the rainy season, the ideal sample size is greater than 14, 17, and 6 in native forest, pasture, and Cerrado, respectively. However, according to the authors, to collect a high number of species, it is more important to sample many times in a year than to collect various samples in a given season, because sporulation varies greatly throughout the year.

\section{CONCLUSIONS}

- A total of 40 AMF taxa were identified in pasture and riparian forest ecosystems.

- $\quad$ G. macrocarpum and A. mellea were observed in all sites and seasons.

- $\quad \mathrm{AMF}$ species richness varied between sites and seasons, with a tendency toward higher richness in the pasture site in the late dry season.

- The Shannon-Wiener diversity index was higher in pasture soil in the late dry season.

- There was a tendency for higher sporulation in the pasture site in the rainy season and early dry season.

- More than 10 soil samples are necessary to adequately determine AMF species richness in pasture and riparian forest ecosystems located on the banks of the Madeira-Mamoré River in Guajará-Mirim, Rondônia, Brazil.

\section{REFERENCES}

ASSIS, P. C. R.; SAGGIN JÚNIOR, O. J.; PAULINO, H. B.; STÜRMER, S. L.; SIQUEIRA, J. O.; CARNEIRO, M. A. C. Fungos micorrízicos arbusculares em campos de murundus após a conversão para sistemas agrícolas no cerrado. Revista Brasileira de Ciência do Solo, Viçosa, v.38, n. 6, p. 1703-1711, 2014.

BI, Y.; MA, W.; FU, X.; GAO, Y.; LI, Z.; CHEN, C.; UM, X.; LI, X.; ZHU, X. Diversity and specificity of arbuscular mycorrhizal fungi in the rhizosphere of six plants in the Songnen grassland, China. Ecoscience, Quebec, v. 27, n. 1, p. 11-21, 2020.

BOERAEVE, M.; HONNAY, O.; JACQUEMY, H. Local abiotic conditions are more important than landscape context for structuring arbuscular mycorrhizal fungal communities in the roots of a forest herb. Oecologia, Germany, v.190, n. 1, p.149-157, 2019.

BRAGHIROLli, F. L.; SGROTT, A. F.; PESCADOR, R.; UHLMANN, A.; STÜRMER, S. L. Fungos micorrízicos arbusculares na recuperação de florestas ciliares e fixação de carbono no solo. Revista Brasileira de Ciência do Solo, Viçosa, v. 36, n. 3, p. 733-743, 2012.

CAMARA, R.; PEREIRA, M. G., SIlvA, C. F.; PAUlA, R. R.; SILVA, E. M. R. Fungos micorrízicos arbusculares em dois fragmentos florestais de restinga periodicamente inundável em Marambaia, RJ. Floresta e Ambiente, Seropédica, v. 23, n. 1, p. 33-42, 2016.

CAPRONI, A. L.; FRANCO, A. A.; BERBARA, R. L. L.; TRUFEM, S. B.; GRANHA, J. R. D. O.; MONTEIRO, A. B. Ocorrência de fungos micorrízicos arbusculares em áreas revegetadas após mineração de bauxita em Porto Trombetas, Pará. Pesquisa Agropecuária Brasileira, Brasília, v.38, n.12, p. 1409-1418, 2003.

CHEN, M.; ARATO, M.; BORGHI, L.; NOURI, E.; REINHARDT, D. Beneficial services of arbuscular mycorrhizal fungi - from ecology to application. Frontiers in Plant Science, San Diego, v. 9, p. 1-14, $1270,2018$.

CRISTO, S. C.; FORS, R. O.; CARVALHO, A. G. Diversity of arbuscular mycorrhizal fungi in pasture areas in the Serra do Itajaí National Park. Revista Brasileira de Ciências Agrárias, Recife, v.13, n. 1-7, e5513, 2018. 
DONAGEMMA, K. D.; CAMPOS, D. V. B. de; CALDERANO, S. B.; TEIXEIRA, W. G.; VIANA, J. H. M. Manual de métodos de análise de solo. Rio de Janeiro: Embrapa Solos, 2.ed., 2011, 230p.

GERDEMANN, J. W.; NICOLSON, T. H. Spores of mycorrhizal Endogone species extracted from soil by wetsieving and decanting. Transactions of British Mycological Society, Cambridge, v. 46, n. 2, p. 235-244, 1963.

KUMAR, A.; SHAHBAZ, M.; KOIRALA, M.; BLAGODATSKAYA, E.; SEIDE, S. J.; KUZYAKOV, Y.; PAUSCH, J. Root trait plasticity and plant nutrient acquisition in phosphorus limited soil. Journal of Plant Nutrition and Soil Science., Chile, v. 182, n. 6, p. 945-952, 2019.

MIRANDA, J. C. C.; VILELA, L.; MIRANDA, L. N. Dinâmica e contribuição da micorriza arbuscular em sistemas de produção com rotação de culturas. Pesquisa Agropecuária Brasileira, Brasília, v.40, n.10, p. 1005$1014,2005$.

NOGUEIRA, L. R.; SILVA, C. F.; PEREIRA, M. G.; GAIA-GOMES, J. H.; SILVA, E. M. R. Biological properties and organic matter dynamics of soil in pasture and natural regeneration areas in the Atlantic forest biome. Revista Brasileira de Ciência do Solo, Viçosa, v. 40, p.1-13, 2016.

PEREIRA, C. M. R.; SILVA, D. K. A.; FERREIRA, A. C. A.; GOTO, B. T.; MAIA, L. C. Diversity of arbuscular mycorrhizal fungi in Atlantic forest areas under different land uses. Agriculture, Ecosystems and Environment, China, v.185, n. 1, p. 245-252, 2014.

SANTOS, T.P. GRANHA, J. R. D. O.; BERBARA, R. L. L.; SANTOS, T. P.; MORAIS, W. P. Fungos Micorrízicos Arbusculares em Floresta Nativa, Cerrado e Pastagem no município de Guajará-Mirim/RO como bioindicador de estabilidade. Meio Ambiente em Foco, Belo Horizonte, v.5, n. 1, p.44-55, 2019.

SCHENCK, N. C.; PEREZ, Y. A manual of identification of vesicular-arbuscular mycorrhizal fungi. Florida: University of Florida, 2 ed., 1988, 241p.

SCHILlinG, A. C.; BATISTA, J. L. F. Curva de acumulação de espécies e suficiência amostral em florestas tropicais. Revista Brasileira de Botânica, São Paulo, v.31, n.1, p.179-187, 2008.

SILVA, F. de A.S.; AZEVEDO, C. A.V. The assistat Software Version 7.7 and its use in the analysis of experimental data. African Journal of Agricultural Research, Nigeria, v.11, n.39, p. 3733-3740, 2016.

SILVA, C. F.; PEREIRA, M. G.; SANTOS, V. L.; MIGUEL, D. L.; SILVA, E. M. R. Fungos micorrízicos arbusculares: composição, comprimento de micélio extrarradicular e glomalina em áreas de mata atlântica, Rio de Janeiro. Ciência Florestal, Santa Maria, v. 26, n. 2, p. 419-430, 2016.

SOUSA, C. S.; MENEZES, R. S. C.; SAMPAIO, E. V. S. B.; LIMA, F. S.; MAIA, L. C.; OEHL, F. Arbuscular mycorrhizal fungi in successional stages of caatinga in the semi-arid region of Brazil. Ciência Florestal, Santa Maria, v. 24, n. 1, p. 137-148, 2014.

STÜRMER, S. L.; SIQUEIRA, J. O. Species richness and spore abundance of arbuscular mycorrhizal fungi across distinct land uses in Western Brazilian Amazon. Mycorrhiza, Beijing, v. 21, n. 4, p. 255-267, 2011.

WINAGRASKI, E.; KASCHUK, G.; MONTEIRO, P. H. R.; AUER, G.; HIGA, A. R. Diversity of arbuscular mycorrhizal fungi in forest ecosystems of Brazil: a review. Cerne, Lavras, v. 25, n. 1, p. 25-35, 2019.

ZHANG, Y.; GUI, L.D. \& LIU, R.J. Survey of arbuscular mycorrhizal fungi in deforested and natural forest land in the subtropical region of Dujiangyan, southwest China. Plant and Soil, Suíça, v. 261, n. 1-2, p. 257-263, 2004. 